\title{
Poverty in the United Kingdom
}

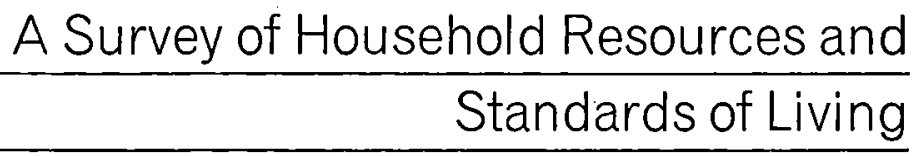





\section{Poverty in the United Kingdom}

A Survey of Household Resources and
Standards of Living 
University of California Press

Berkeley and Los Angeles

Copyright (C) Peter Townsend, 1979

Is B N: 0-520-03871-1 (cloth)

I S B N: 0-520-03976-9 (paper)

Library of Congress Catalog Card Number 78-66023

Set in Monotype Times

Printed in Great Britain by

Hazell Watson \& Viney Ltd, Aylesbury, Bucks 